GIBBS

Trees and Shrubs

adapted to

Central Ilinois
Botany

B. S.

1900

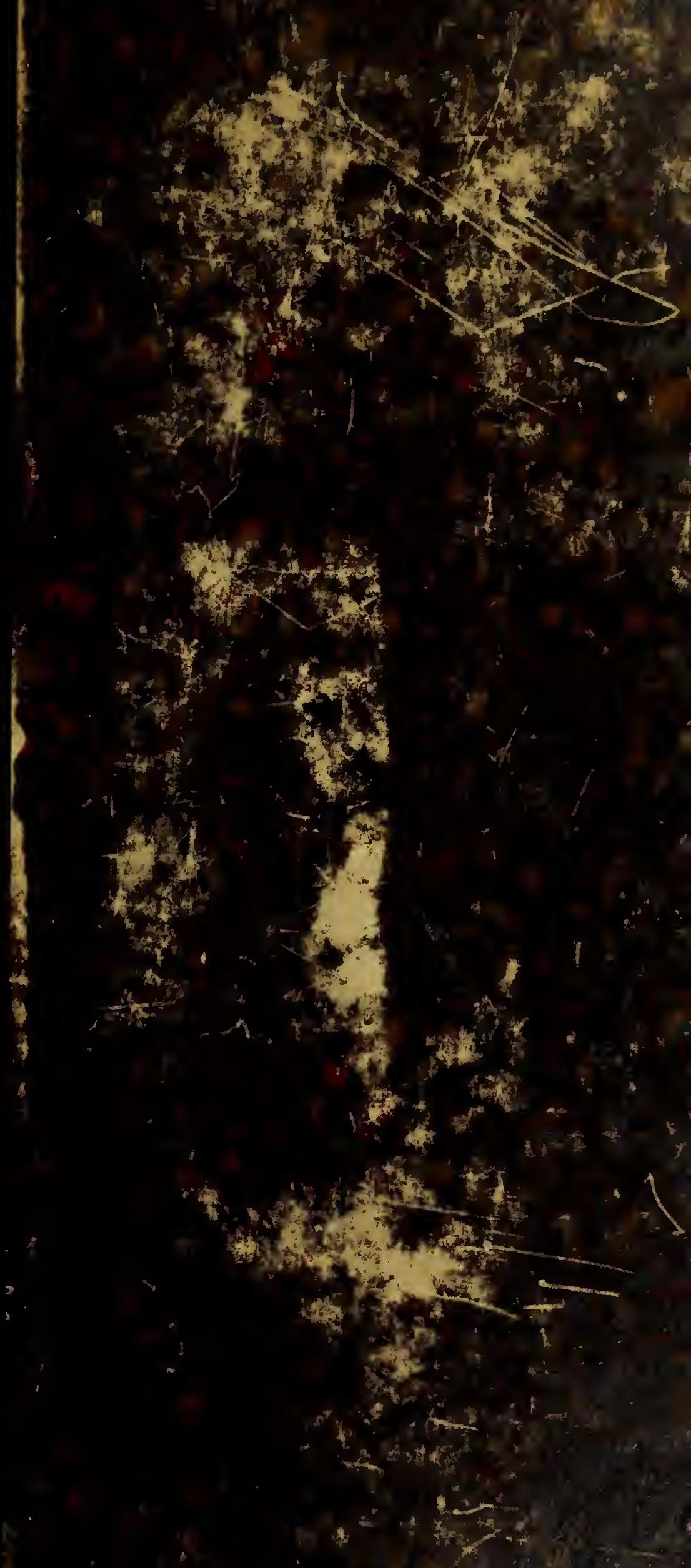






\section{Digitized by the Internet Archive in 2013}



<smiles>CCC</smiles> 


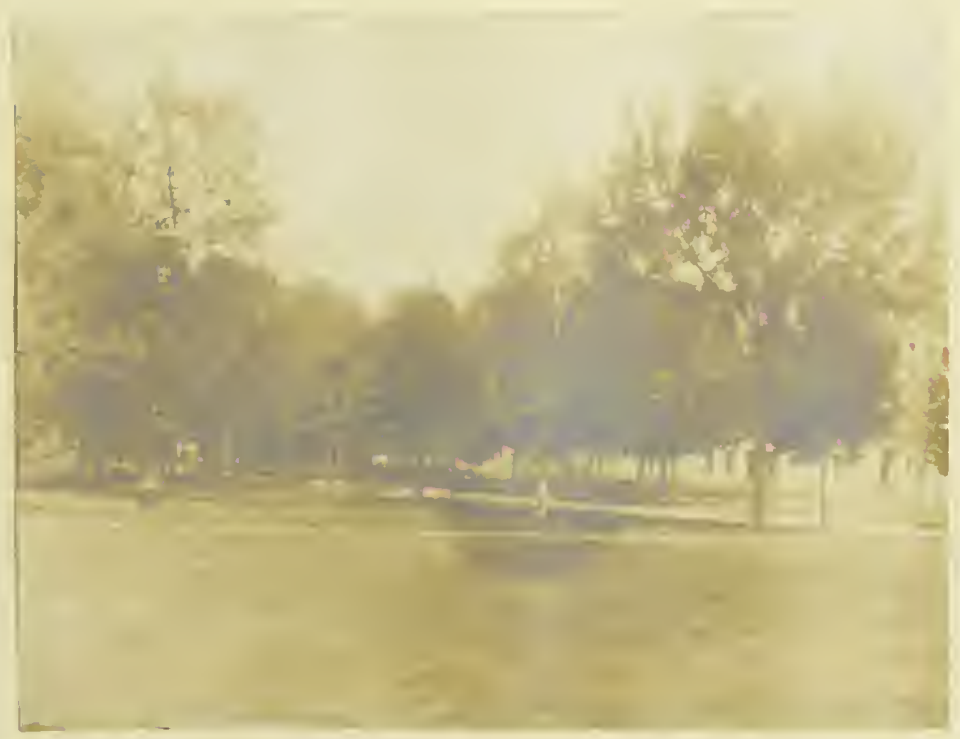





\title{
NOTES UPON
}

\section{TREES and SHRUBS \\ ADAPTED TO CENTRAL JLLINOTS \\ With especial reference to their value in omamental planting}

\author{
BY \\ GEORGE GIBBS JR. \\ $-11-$ \\ THESIS
}

For degree of Bachelor of Science in the College of Science INTHE

UNIVERSITY OF ILLINOIS
PRESENTED JUNE 1900



WNIVERSTTY OF ILLINOIS

Alaysi,....

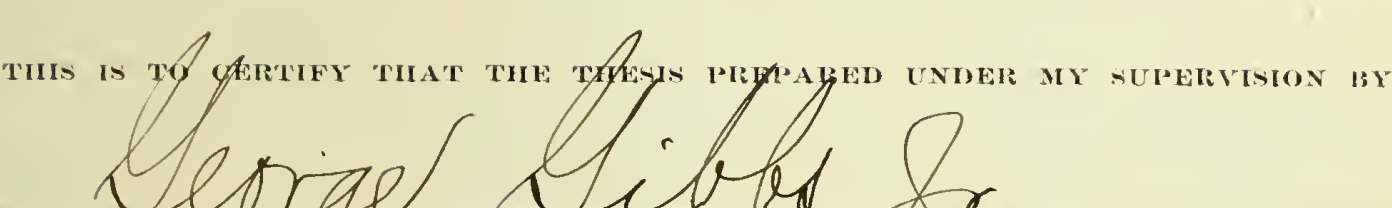

cenger Libas

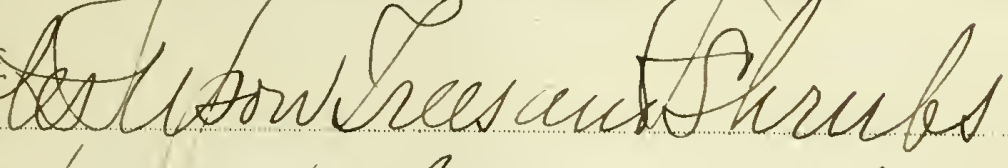

Adasted to burrablelinas

- Bachelor of atécued

DPurrill.

Dotany 
(60) 
NOTFS UPON TRFES ANH SHRUBS AJAPTED TO CFNTRAI, TI,IMOIS.

As far as possible a complete list of the trees and sirubs, both indigenous ani introduced, that are adapted to central Illinois has been made in this study. It has been the endeavor by this means to get at the origin and the value of the material to be had for park and ornamental nlanting. Champaign has been the center of action, while all possible data have been obtained in regard to the surrounding country. Although it has not been practicable tc obtain the facts concerning a II plants grom in this region, some data, at least, have been gatlered relating to ali our common trees and shrubs.

In addition to actual observation in the field a study has been made of all the articles found in the library. The hooks that bear upon the subject may be divided, for convenience into four classes as follows:

1. Text books, manuals, and general works.

2. Workis upon forestry.

3. Nursery catalogues, and lists.

4. Fragmentary and special articles, consisting of theses, 

monogranin, manazine articles, eto.

$$
\text { I. Text-buoks, Manuals, etc. }
$$

Apgar, A. C. Trees of the Northern United States, 1892. Very good; includes native, and many introduced srecies. Liv. G. G. Jr.

Benthus and Hooker. Genera Plantarun, 1870, Latin; in three volumes; gives all known genera of plants with their distribution.

Britton and Brom. An IIlustrated Fiora of the Northerm United States and canada, 1896. The nost complete manual puolished. Does not include many cult. species of foreign origin. Brom, D. J. Trtes of North America 1840. includes foreign trees grown here, but not complete. 0?a.

Chepman, A. T. Flora of Southerm United states, first ed. I860, others since ther (1834). Best manwal of that losality. Cooper, J. G. List of trees geograpinisaliy, I858; in Proc. Smithsonian Inst.

Damberry, Chas. Popular ieogranhy of Plants, 1855.

Emerson, George B. Report oll Trees and Shrubs fonming Naturally in Forests or wass., 1875. Very good as a reference book. Gray, Asa ( 1 ) Field Forest and Garden Botany, 1895. Especially given to cultivated plants.

(2) Flora of United States. Synoptical, 1884. Z Vol. (3) inanual of Botany, Sixth ex. 1889. Host convenient 

for field work, not so full as Rritton and Prown.

Kermer and Oliver, Natural History of Plants, 1895. In 4 Vols;,

large iliust. Valuabie as a nopular mork.

Lindlay and Hoore, Treasury of Botany, London, 1840. UsefuI

for reference mork.

Vacirilan, Mimesota Plant Life. hetaspermae of Minn. Valzey 18n2. Michaux, I. A. The U. S. Sylva, 1859. 3 Vol. colored iliust. Neminall, Trees of Northeastern unitod states. In Cham. Lib. Nuttall, Thos. North American Sylva, I859. A continuation of michx. 2 Vol. colored iliustrations.

Sargent, J. 5. (i) Unites states Forests. Ioth Census Vol.a. Gixteen coiored ians.

(2) Sylva of the United states. I2 Vols.

Large.iliust. by half tones; these, however, of only fragnents, no whole trees shown.

Suämorti, G. 3. Nomenclature of United States

Arborescent Flora. Inited states BuI. 14. Een. Agr.

Div. Forestry, symonomy, but no jescrintions.

Vines, s. H. Text-book or Botany, 1895.

Toushes upon paleoisotany, gooz on floral parts and relationships.

Waming and Potter. Systenatio Botany, 1895. Very full on plant nistories and relationships. 

I I. Works Unon Forestry.

Brom, Janes (I) The Forester. Ediniurg I87I.

(f) Several local works, both practioal and histori-

c?.1.

Carriere, Les Arbres et la civilization. 0ld.

Coibett, Wru. The Woodiands.

Fuller, A. J. Praztical Forestry, 1889. A description of indigenous and exotic trees.

Fuller, A. S. Forest Tree Culturist, l870. iliust. wyood cuts.

Hourh, F. B. Flcixhts of Forestry, I89?.

lieenan, Tios. Amerian Hand-book of omanental Trees, 1853.

Sma11.

Reports. Eorestry Comissioners, Govemment Renorts, and Public Incluments.

III. Nursors Co.tcologues, ets.

Andorra Nurseries, chestnut HiIi, Pa.

Filnanger and Barry, Rochester, N. Y. Very good.

Greening Bros, jomroe, Nich. Wlostly fruits.

Ivson and Bogus, Indianapolis, Ind.

Thos. jueeinz and sons. Gemantom, Pr.

Phoenix ivurscy, 31oomington, III.

Reading ivursery, Rending, hass. jost complete.

Storrs and Harrison, Paincsvilie, Onio. 

IV. Specinis, Exnghertaries, ets.

Brontel, Flora peoriana, 188:.

Bulliari, Flora parisicusis, I7ro. f Vol, colored illust.

coleman, \%. S. Our woodlands, leaths, and Hedros. Londor, 1360.

Filemantary; rives inserts.

clintol, G. P. Flora gumpaign Co. Fhesj: and gard gitalozue. Gray, Srn'i. British Plants, 1821.

Gordon, Pinetur, 1870. Complete manual of conif'crae. 500.p.p. Holston, 3. 3. Study of Timber Trees of Washington Co. Ill. 1894

Honnes, Book of Evergreens, 1868.

Knobel, E. Guide to Trees of Ie" England by treir 1enves. I834' Iii). $r_{x} \cdot\left(x, j r^{2}\right.$

Ihegazing, renort, of Gardens, etz.

An. Jaturailist, solne good articies. Fen on botany.

Am. Jl. Soience, formerly Siliman's jl. Austruse, but fem artises on botany.

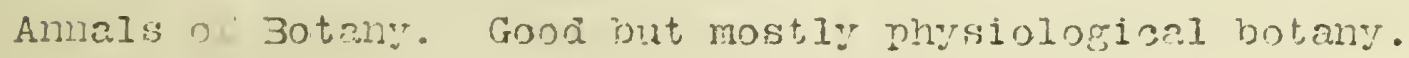
Annals of Natural History, Botany. Prencin.

Botaniznl xazette.

Bulletin ive" York Botanieal Gardens.

Bulletin Boston Park Improvenent Assooiation. INot in our In. Edinkurg Ji. So.

Gorien ani Forest. Fine, but disoortimued. 

Honker Jl. Botany.

Journal Lin: Societ: .

Weenans wo thly

Iltssouri Botanisal Garden Report.

Ivature. Ponular sinall magazine.

Parh and Cenetery. Not in our Linrary.

Popular science wontinly. Fom artickes on Botany.

Science, popular magazine, some gook articles on Botany.

Torrey Brlletin.

Torrey i.sunirs.

Irans. Isini. Society .

Louilifort p'. Trait, des Ariores et Arorisseau, 1891. 1500 p.p. on woody f'lora of Europe, especially of France.

Fron a comparative, stuay of hese books together with oiservations and field notes a list has been made of woody plants that are adanted to our conditions. In these investigations the purpose has been to answer three questions; first, mhat trees and shruis should me find; second, what do we find, and third, where did the: come from.

To discover what plants should grom here, it is necessary to kno"' what our environments are, and also what is the history of the changes th soil, clinate, ets.. for such events concem the agents mich moula enable these plants to grom. Central Ilinois is sittiated in a glacial region with a soil maje up or many kinds of matcri- 

als brought here by the ice.

In some places the surface is con posed of gravel or of' clay and is only fairly produstive, but in general we have a deep layer of very rich and produrtive humic soil. our climate is temperate, thougin subject to high winds, and to sudden changes of ternperature. The flor of this country was all destroyed during the glaci.l. neriod, by ice coming dowr from the north, consequently we now have a sollection of plants that have jmmirrated from tha souti and from the north, making for uso a new and varying flora. North America as a whole is very rich in trees and we are located in the area of greatest development of deciduous trees. Therefore, we showld expect to find all plant; that grow in rich soil in the temperate zone and that are able to resist sudder changes in cIjmate, high winds and hot sun.

While we should expect a great variety of trees and sirubs, the distribution has been checked by several obstacles. A large per cent of Central IIlino is was covered with prairie sod; this sod, once established, has been a very fornidable barrier to the spread of other plants. Fire driven by strong winds has destroyed forests and given the advantage to tho sod. Probably the wind unchecked, as it is in such a flat country, has also acted directly by breaking dom our trees. Therefore we do not find as good native, woods as we should. However, since the land has been under cultivation the true possibiIites of our locality have been demonstrated, and we find that a large variety of plants will do well here when circunstances are favorable.

The third question to be considered in our flora, is as to where our plants came, from. The land must have been left in a varen condition by the retreating glaciers, and open to the first plants that 

entered. The water courses towrol the south fomed good channels of distribution, so a large number of our plants carne from that direstion and ontained wide distubution aided as they were by wind, njeratjug bixds, and the various sources of seed transportation. From the north carne a number or other nlants, but in sraller quantities than from the semi-tropical regions. In addition to this netural distribution the hand of man has played a prominent part. He has imported plants from the east and west where migration has been checked by mountain ranges and oceans. Many of the old worll nlants have beer successful. ly Erown here, and the Orient, especialiy tapan and china, is becomins an important source for new species. In order then to trace the orjgin of our flora, wo must consider the work nature has done from the north and the south, and the influence exerted by man from east and west.

Oux woody flora nay be divided for convenience into trees, including all perennial woody plants that rise from the ground with a single rigid trunk; ard shrubs including "ooly peremials, not trees that persist above ground; this latter class will also include the few woody pexsistent vines. This clisfificrtion is not scientific, nor is it a rigid one, but it affords popular lines of. distinction. The order of families and genera as given in Britton and Brown's ililustrated flora has been followed, and only tho se plants that have grown well in our locality have bepr: considered as adinted to this region.

\section{TREES.}

The trees belong to two distinct classes according to the character of their fruits, the gymnosperms with naked cvules, and the 

angionnersm: with ovules end osed in an ovary. The rimst, class consints chiefly of evergreen trees; the sesond chiefly of deciduous troes and sinrubs.

Tyunosperms.

Nostly evergreen troes with noedle-Iike leaves. I he trees of this class prefer in seneral a granitic derris with a dm subsoil. However, four spcoies are indigcnous to tris part of our state (pinus strobus,P.Banksiona, Juniperus Virginiana, and Phuja ocoidentalis), and a number of others do well here.

Fanil: Pinaceae Conifers.

PINUS.- Fine. Wostly large trees comon in cultivation.

P.stroius L. Wite pine. TiId in northern part of the state Where it porms a very large tree; nere, foms quite large handsolse speciliols in cultivation.

P. resinose Ait. IJomar pine, Red pine. Tinrives in our soil, forms mediun sized tree, with crooked branges, and reddish vellow Bark.

P. Austriaco Hoss. Austrian Pine, Black Pine, cultivated from Europe. Very voricible.sunetinos. makes a very hanzsone specinen if allowed to irrincin near the ground.

P. Sylvestris s. Sootcin Pine. Cultivated from Enrone, common, 



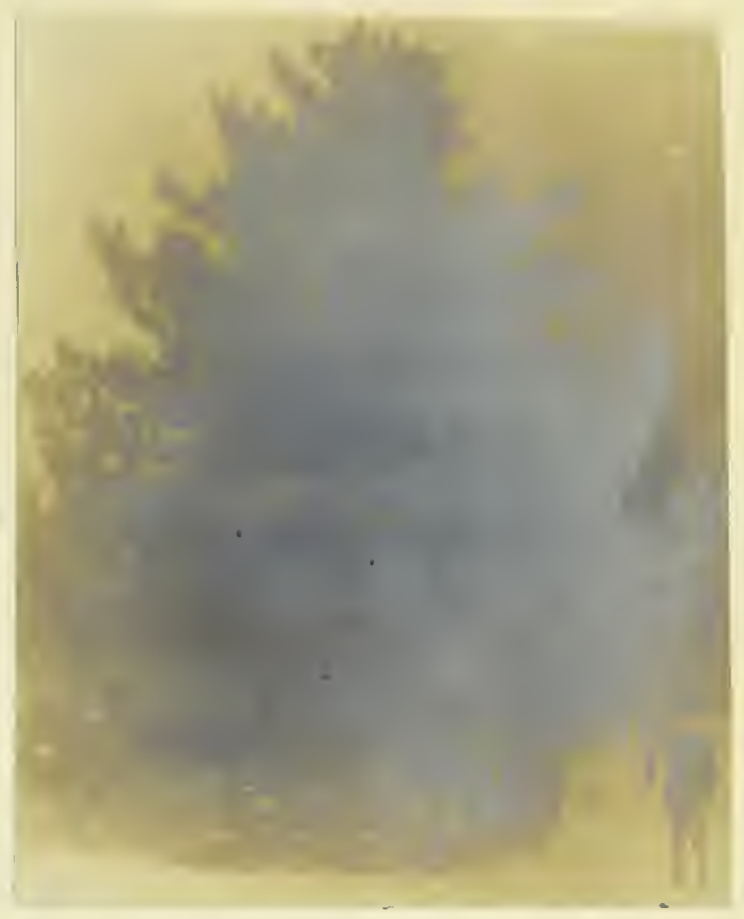

Pinus Austriaca

Austrian or Black Pine

Pinus strobus.

White pine. 

forits 1 arrege trets.

P. divarigata (Att) Soruib Pine. Along streans.

LARIX. Iaroh. Deciduous, but leaves out very enrly.

L. Arnericana inicin. Arneriond Larch.

Wild in northorn IIIinois, sometines oultivated. Forins a large pyranidal tree with arooning brancinlets.

L. Furonaed Ix. European Laroh. Cuitivated Iron Eurone; Iarger ans more selisnte and drooning than above, more used in cultivation.

FICEA. Snruse.

P. exceliso Link. Nonmay spruce. Conmon in cultivation;

formis a large tree with tall snire and stout horlzontai branches with drooping isranciets.

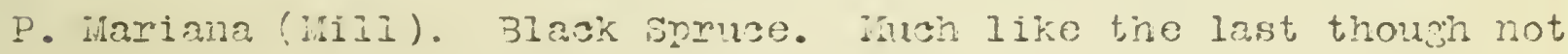
so tall, native fartier nortin. Comon in oultivation.

P. nmgelus Engin. Coiorndo Blue Bnruse. Oconsionally mitivated, from Rocky Mountains.

PSEUDOTSUGA.

P. taxifolia ( I,am.) Douglas spruce. A very large groming tree reontiy introdused from the "est, no large snecimens are found here, iut the young trees rrove hcray. 

TSUGA.

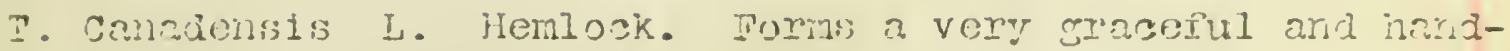
sone tren if allowed to uranch near the sround. cultivated.

ARIES, Pir Iroes. Not so mugred and striking as the spruces. A. Balsanea L. Baisam Fir. Often cultivated; forms a mediun sized pyramidal tree.

TAXONIJM.

I. distiolum (L). Bald Cypress. A large groming irregularshaped tree, comon in soutinem part of the state. Cultivated here, forms mile young, tali, conical, resular shaped tree. Leaves pimate, deliscte, decicimous.

$$
\text { THUTL. }
$$

T. Oosidentals I. Aroprvitae. Srail tree or sinrub, Mild and cultivateä, comon.

JUNTPERUS. IWO OI the Cour North American species sro" here, especieliy in cenetsies in cultivation.

J. Commis i. Comon Juniper. Profers atrin soil, is Iiable to rot in our rich loan. A variety, Jibernica, forming a slender conisei or columar smaIl tree, is a favorite in cultivation. J. Virginiana L. Red cedar. Cuitivated and in woods, forms larger tree than above species. 

Taxazere. Yem Enmily.

GINicro. A very old genus with only one species itving.

G. Bilnise L. (Balisburin adiantifolia). daiden Hair Tree. Orten cutivated, forns a large tree of fine sinne, seens rerfectly harzy.

\section{Allogiosnerms.}

We find nost of our trees and shruis belong to the class of Angiosperus. The moniands here, thow sonarnted by large areas of prairio land, cortoin a jreat variet: or plants. The varieties found, however, var: eroatiy, for even adjoining losalitics, due in part, to the newess of the rlora and the urequal distribution that has ocourrea since the flasial period, but it is fourd by experinent that the plants tint ycom anywere ir this region, wiI grom almost evervmere herc, men trousnlaitea. The florn of this georranical area is espesiclly mericed bu the ingh develonment of its deciduns troes, thorefore the Iist ni tian is Pound to ie largo.

IHONOSOTYTIOHS. No trees excent in tronics.

IICOTLEDON3. Sten foried of pith, mood mi iark increasing in size by amuri ingers.

$$
\text { Juglandaceae. Talmut indiy. }
$$

JUGLAis. A genus of loge nondsone trees with sneading uranch- 



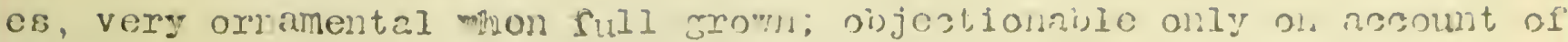
strong aroun froll their ioaves.

J. nim I. Black Walnut. Native nore, fond of ricin soil.

J. Cimera I. Buttermut. Like the anovo, native here. Hot so good as nigra for orramental pianting as it is coarse, and has fomer branchlet:s.

J. Siemndian waxin, Jananese valmut. A nediun to large-sized tree cultivated froln Japan. Hardy at, $\Lambda$ grimutural Experinent jtation.

HICORIA. Rar. jickory trees. Calied by cray carya. He are near the contor or distribution. Four spocics grom "rid in this county and three otrerg heve been revorted from this region.

H. Pecan (Warsh). Pocan mut. A lerge slender tree, occurring in Moodis in some rerts of the state.

H.minim (:arsin). Bittemut. A mediun to large slender tree; common in monis.

H. ovatr. (Jill) shagoark. Also comon, forms larre tree "ith very rough jark.

H. laciniose (nichx). mins nut. Larre, handsone tree, abmdant in wooks.

H. albr ( 1, ) jockernut. White Heart Hickory, sommon in moods. H. nisrnanr? (Nutt) Small fruited hickory, reported from Macon count: III., (GI)

H.glabre (iiliz).pignut. Renorted from Peoria. (BI). 

Salicnotas.

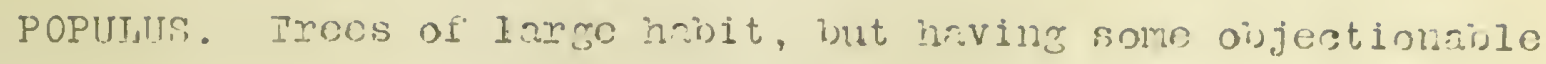
features. The: are contimally shoding fruit bark or foliage.

P. albe i. White or silver-Leal poplar. Comon in cultivation; from Europo and Asia. Torms large, broad-topned tree.

P. Grandidentrote ifichx. Large-toothed Aspen. Ocours in our moojs, cormor in cultivation, has goos form, but is afreoted by mind and by insects.

P. tromulnides, Lishx. Quaking Aspen. Froms here in gultivation, and in solue locklitics wild. It is the smallest of the poplars, forty or firty peet hion.

P. disatrate Mit. Lomordy poplar. A common tree in eultivation; groms very tall and slender. Of littlo value in small pianting, though orter. wsed.

P. doltoides iarsh. Cottonood, Carolina Ponlar. is very ranid growing trow that stemäs transnlanting meli, not good for a permanent specinen, oming to short life and weak annearanse.

SAJIX. A rrour of trees mhose species are very harg to identify. owing to lask or mater in the list hes not been completed.

5. nigre linssh. Black wiIlom. Comon along our streans.

S. amrgdaloldes Auders. Peach-leaved wiliom. Reported from

Peoria ( 32$)$

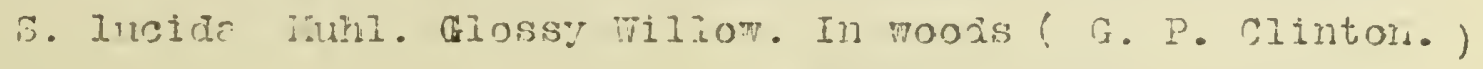





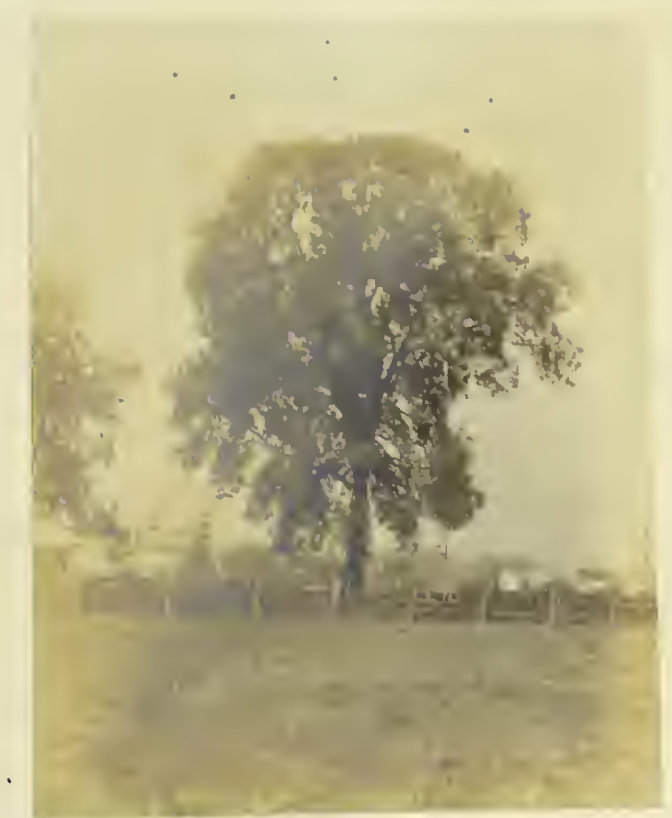

Populus deltoides.

cottonwood.

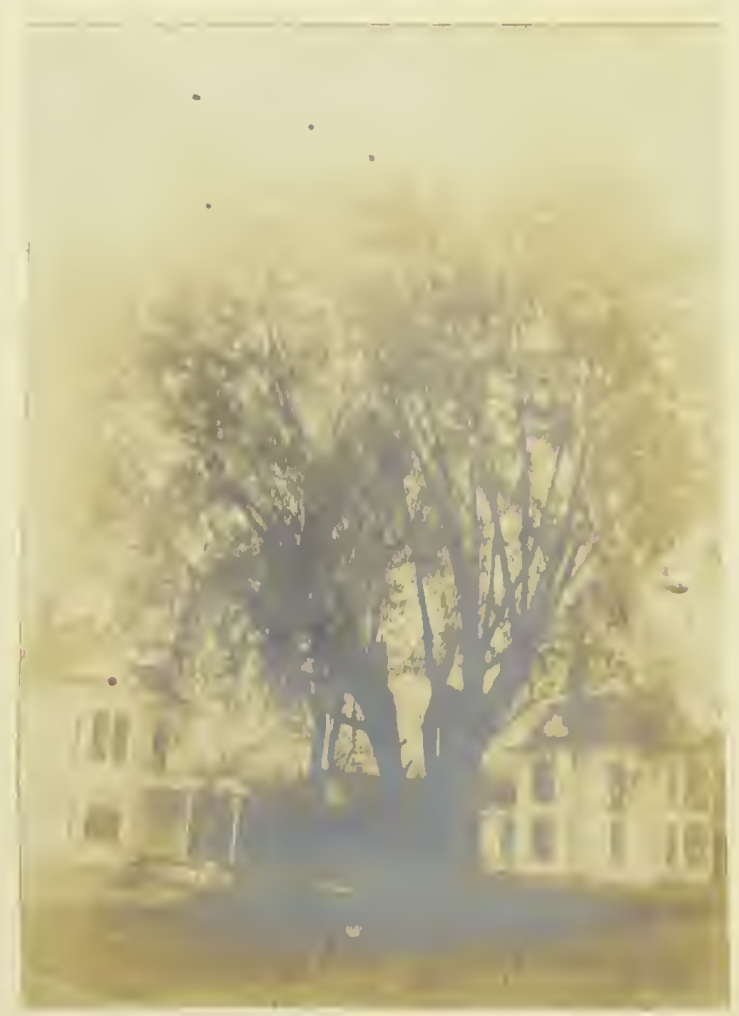

SaIix Alba.

White Willow. 

S. alba $T_{1}$. White Willow. Torms a large tree, often cultivated for ornarnent and shade. From isurope.

S. Rabylonica $r_{s}$. Weeping, Willow. A large handsome weeping tres, often cultivated, especially in cemeteries, also urseful in parks. Native of Asia.

S. fluviatilis Nutt. A much branched sirub. Renorted by G. P.

clinton.

S. humilis Marsh. Reported from Peoria (BI).

S. Tristis Ait. Reported from Pecria. (BI).

S. discolor Munl. Reported frorn Peoria. (BI).

S. Serice Marsh: Reported from Peoria. ( $R \mathrm{~L}$ ).

S. candida Fluegge. Sirub. Reported from Peoria. ( RI).

S. cordata MuhI. Penorted from Peoria. (RI)

S. myrtilloides T. Reported from Peoria. ( $B I$ ).

Retulaceae.

CARPINIJS .

C. Crmolinjana Walt. Blue Reach. A shrub or small

tree found in thickets along streams.

OSTRYA.

0. Virginica (Mill). Hop Hornbean. Ironwood. A small tree; cormon; its leaves much resemble the elm.

CORYLIS. See shrubs.

BFituA. Aromatic trees belonging chiefly factier north. R. papyrifera Marsh. Canoe Birch. Often cultivated; forms a graceful tree, especially good with evexgreens. 

3. nimr? I. Black Biroh. Common ai ong streans. (T.J.3.)

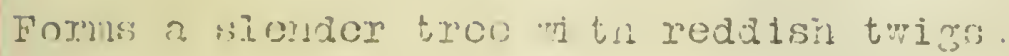

3. alb i. Furnpeah. White 3irch. Often cultivated, especialiy in sutlens and "eering varieties.

3. lenta L. Themry or Bmeet Blroin. Renorted from int. Camel. I.1. ( seymour).

AINUSS.

A. Glutimoss (i) Furonean Alder. A nediun-sized tree, ocresionc.liy ourtivatod, quite ommental.

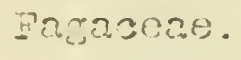

ZASTANEA

c. dentete (iramsin). Nerionil Chestnut. Cocasionally oultivetel here, welorgs farther east.

QUERIU.s. "To are in the ares of rreatest develoment for the oaks, and just rest of the center of distribution, our woods contain ten or t:"elve "wij srecies. They form valuaile timer troes, and are very use cur cor ormantent pinting.

Q. ruibre I. Red Oak. One of our first-olass large trees, conmon in "poas; xsurily of irrentar shone. Ornanoutal when pronoriy planted.

n. nalustris IuRoi. Pin Oak. Ocours ill damn mooủs.

Q. velutins Lam. Queration. (o.tinctoria) a very large tree "ith armk bark, ani dark meen dull ienves. Occurs in mods; kno'm by orange solor of live isark.

2. nisrn L. Water onk. 3lask Jnok. In coucrol distribution, 



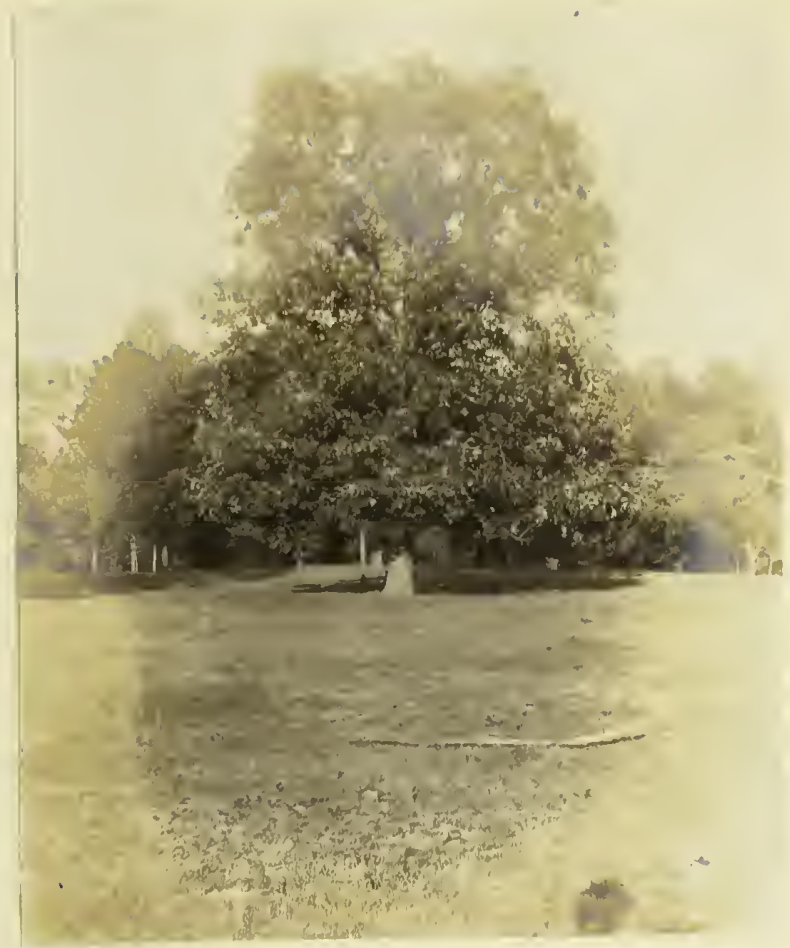

Quercus AIba.

white oak.

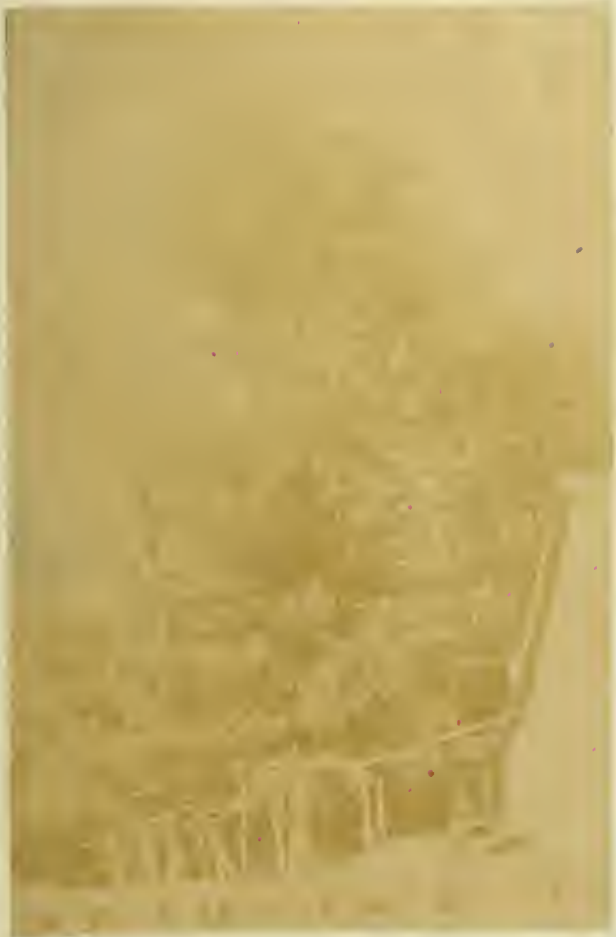

Quercus Rubra Red oak.

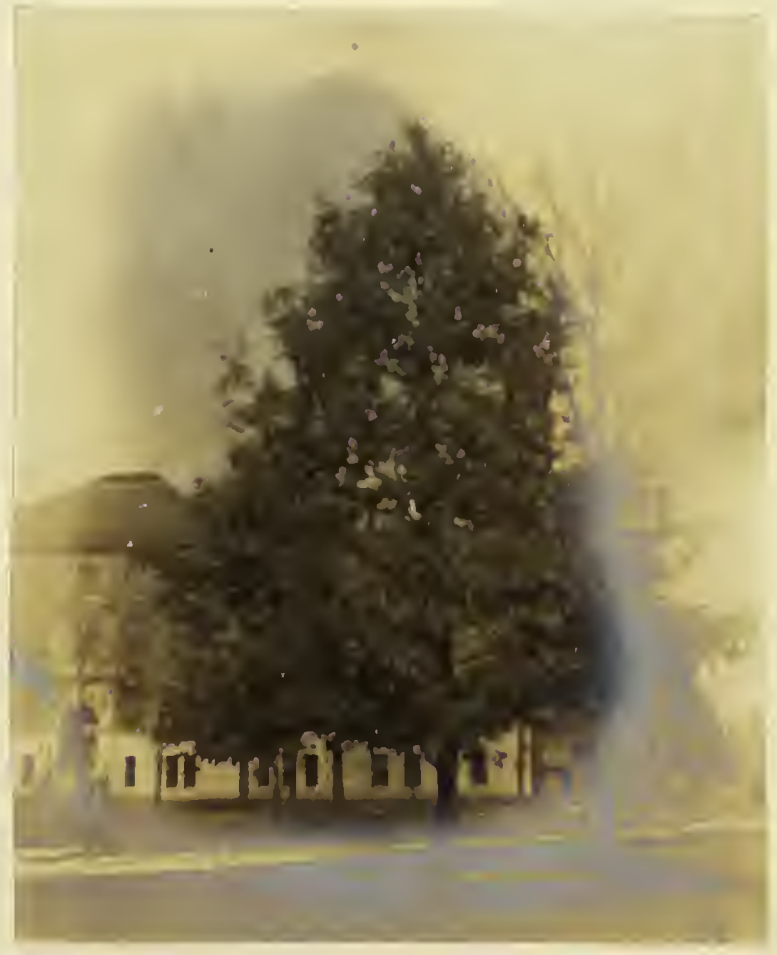

Quercus Robur English Dak. 

forms a sina! I treec.

Q. Irlorigreria dichx. Shingle Dak. A large tree.in moods.

Q. alva L. "rnilie oak. The finest of the oaks, especially for specinels trees. Coumol, groms very large.

Q. rlacrozarpa wichx. Burr oak. In wooas, and cultivation.

1. platanoides (Lam). Smann mite oak. (r.i)icolor). Common in 7002.

Q. accuninata ( aicix), chestmut ork.(Q...inlenoergii). A very larre tree round in our moods.

R. Robur I. Fugisin Oak. Forms a large tree in cultivation.

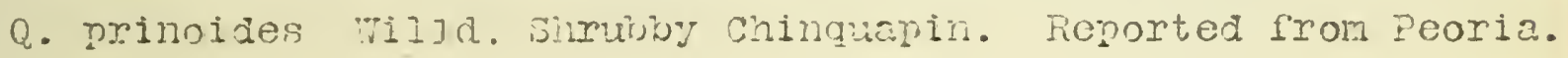

Ulnaseae.

ULiIUS.

U. Amprigoua L. American Flı. Our most useful shade tree, forms a large, rrasorul, open heca. Cormon in aII situations, much usej in cultivation.

U. Rameno:ic Thomas. Cork Eln. Not so large nor so inansone as

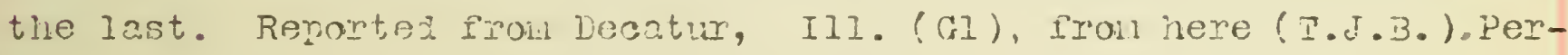
fect 1 yarì.

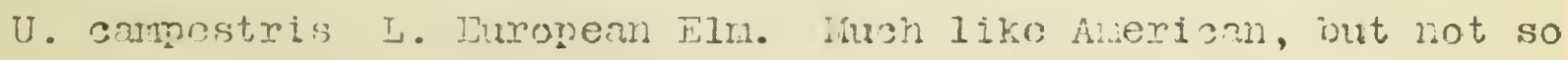
gracof?l, has a aloser head, is more resistant to the "ind in very exposes pleses.

U. fulva :isinx. Slippery Elr. Ocours in mooz̉s. Coarser than U. Amerizanc, not so grood for cultivation. 

U. Ifontane, srafted oul other stock, formis noudsome, pendulois, shrivon tron.

CFITSS.

3. nszidentails L. Haskberry. Cormon in moods and in cultivation; forms a handsone first-olass tree.

vioracene.

NORUS.

in. rubre L. Red hubermy. A nediuri-sized, native tree, ofter cultiveted.

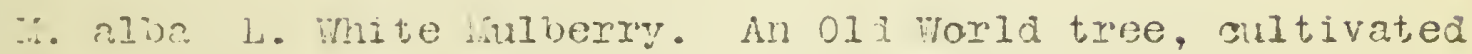
here for fritt. Var.tartarisa. Loudon. Russian iwloerry. Also cultivated for cruit.

ZOXY, ON .

?. noulfomil hai. Osnge orange. A nediun-sized tree, much usm in tie form of shoared heages. Wot cood for ornanental planting.

iragnoliaceae.

Trees or simms coming from the semi-tronical rejions, that stijl retain sone tropisal charaters, onpecially in their large glossy leaves. 

MAGNOLA. No meoles are indigenoun, but several prove hardy. $\therefore$ ascumbate L. Cusumer iroe. A modiun-sized tree, oultivete? here, yrows as par north as uichigan.

ii. magropiylia ulichx. Large-icaved wagnolia. A mall tree Mith vory large Ienves. Reported fron Princeton, Ili. (3ryant,). i. Soulangeane Jananese ingnolia. Fiorms a handsome large shruib with isf ilght colorca flomers. Cultivated.

LIRIOIENDRON. A genus of only one or two speaies, native of

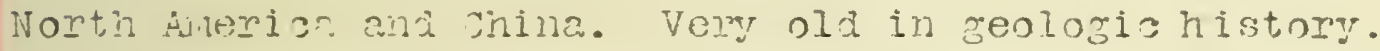

L. Tulipirera i. Iulp-tree. A nagnificent, first-olass tree, inaiginous to nert of thi:; state, coes meli in ultivation.

Anonesene.

ASIMTIA.

A. trilois L. Papam. A small tree, nore often a shrub, contion in moons.

Louraceae .

SAS SAMAS.

j. Jonsciras (L). Sassafras Troe. A nediud-sized tree, "Ith hondsone roliage; common in moös. 

saxifragaceae. See shruis.

Hamame] idaceae.

T, IOUIIJAMRAR.

$J_{1}$. Styraciflua $T_{1}$. Sweet Gum. Grows here, but has not been fully tested.

Platanacoae.

A farnily of one genus of trees found in the north temperate zone.

PLATAwiss. Jarge trees sometines damaged by a fungus.

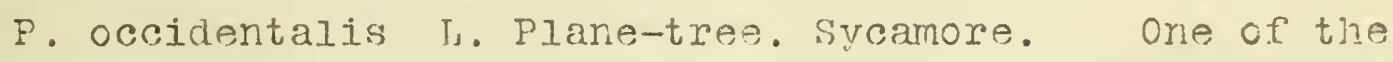

largest trees east of the Rorky Mountains. Comon in river bottons, the largest specimens often holjow.

P. orientalis T. Oriental Plane-tree. Sometimes cultivated, but not so hardy as our sycanore.

Rosaceae. See Shruhs.

Pornaceas.

SORRUS.

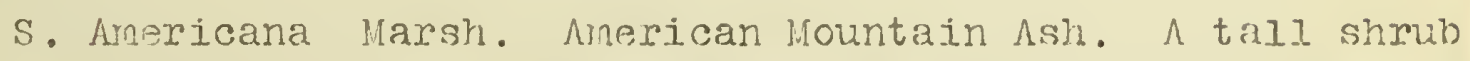
or slender tree.

S. Aucuparia Is. Furopean Mountain Ash. Cultivated from Europe, forns a fine large tree, but rots badly where wounded. 

PYRUS.

P. coltnmis I.. Cormon Pear, cultivated everymere. Hative of Europe and Asis.

P. Gyonia L. Comon nuince. CuItivateä from Eurone.

i.ALUS.

i. angustifolia (Ait) Narrom-lenved crais. A small tree in

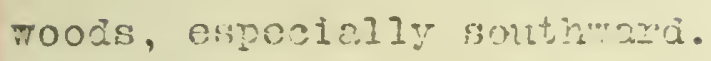

if. omonemie (L). America craib-anple. A small tree in wooss and oultivated, beans large, very fragrant flamers.

w. Inensis (Tons), when like aiove; not, omon here.

ii. inalus I. Coludon Anple of cultivation.

in. Soulariil (3ailoy) A smali unright, stout tree mith

Iarge fruit, one found aloug roadside. vihonet.

\section{ALIELANGHIER.}

A. Canajensis (I) June-berry. Servigo-berry. Along streams, foris a shmis to mediun-sized troe. Does meil cultivated in shrubbery.

CRAIAFTU.

Shmbis or small trees comon in moods; they fom dense olumps, and ore usualy armed with thorns.

D. crus-galli L. Cookspur Thorn. Has especialiy large 

C. cocolner L. Red Inom. Benrs large red edible Pruit.

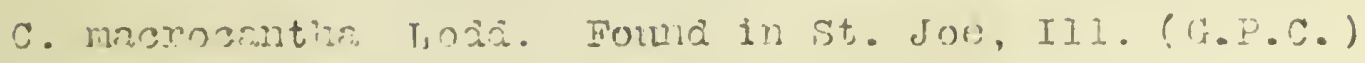

C. molits ( I. onג a.) rmon like C. cocoinen.

c. tonentose I. Pear Ham. Hore liante lcaves ard branches than the others; inore ornarental.

Drmperae. Plur Family.

PRUNUT.

P. Aucricana warsh. Wila Yeliom or Rea Plum. A small tree of litt, Ie value in orrarnental planting.

P. angustifoli? wighx. hemorted fron wenard go. (hali).

P. coresus I. Dour chorry. Comson ir oultivation.

P. Pemsylvaniso L. Wiid Red cherry. Renorted from Ringwood Ill. (Vasey), also from CEle Comty. (T.d.B.).

P. Virginiand L. Choke chermy. A smal tree comon in woods. P. serotina Dinh. Tild 3lask sherry. A large tree in our 700cs.

P. Japonice Thrnis. Cormon Flomoring Alnond. A comon shrub in cultivation.

\section{AMYGDALUS.}

A. Persior L. Peach. Comon ir outivation, often escapes into border of worts. 

Caesalninaseae.

CERCIS.

C. Cencdensis L. Red Hus. Smil tree comon in woons, does rell in suitivation; prominent por pea-like flowers in uay.

GLEDTTSIA.

G. triazantios I. Hone: Looust. A large tree often covered witi thoms, ascesionaliy foind in moods and in cultivation.

\section{GYWNOCLADUS}

G. dioise I. Kentusky coffee Iroe. Gutivatea, and in Toods; Foms a laree ornamental tree with rusged, cluijike, srooked branches, and larre frut poos that orten nang all winter.

Panifionaceae. Pea Fantiy.

ROBIIII.

R. Pseudacacia L. Lomst-troe. A large tree, comnon in cultivation; a poor specinen tree, as it, is baly broken by winds, it is almays in:dinf, and it is ant to stread bady from the root. 

Rutcosere. Rug Fanily.

\section{XANPHOXYLUW}

X. Arurionum wili. Priokly Ash. $\Lambda$ shmb or stall tree, conmon in moosis.

PPELFA

P. tricoilata L. Three leaved Hon-tree. A shrui or small tree in mooss.

\section{simaruisaeae}

AILATPHU:

A. ricmoluosus Desf. Iree of jeaven. A large, rather coarse, rank groming tree; in oultivation and escaned.

Anacoriacseae. Suna: Family. See Binrubs.

celastracene. See sinmiis.

Aceraccae.

Aser.

A. saconarinum L. Sort tanle. A large ornanental tree; 



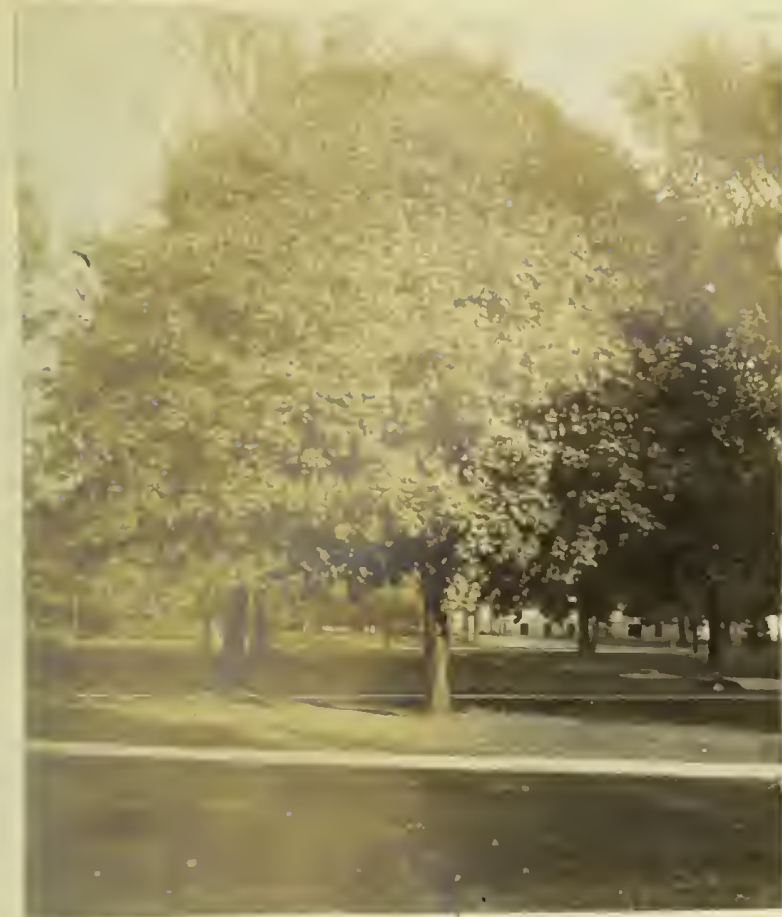

Acer platanoides Norway Maple.
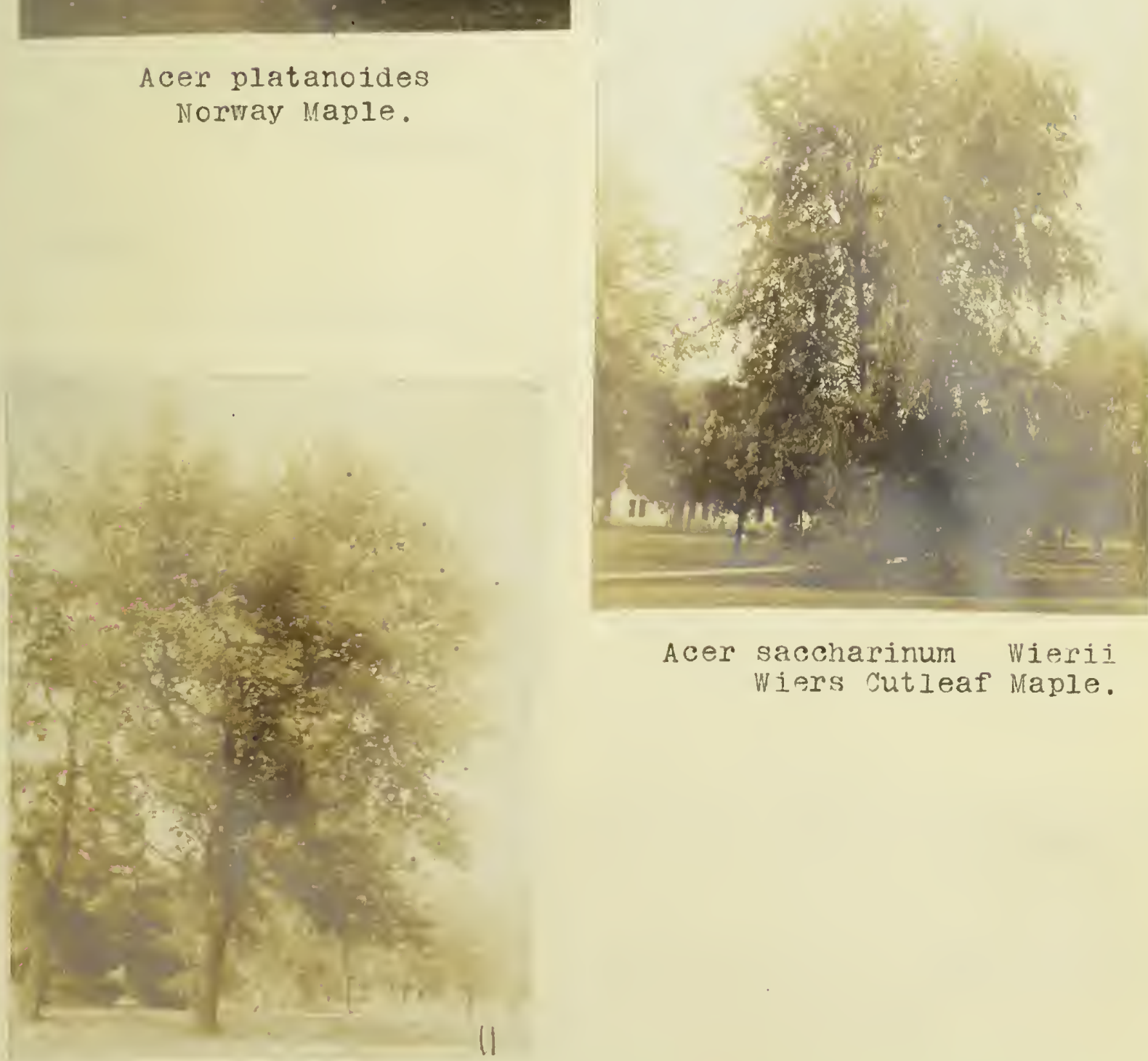

Acer saccharinum wierii Wiers Cutleaf Maple.

Acer Negundo. - BoX Flder 

comion in moosis wid in cultivation.

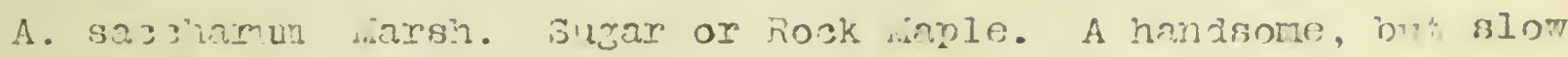
growing tree, very fomal and dense; comon in mooxis and in cultivation.

A. iverudo L. Box Elder. A hardy, ronid growing, mediur sized tree; not very ornoweital, but mon used.

A. platanoides I. idorray daple. A Pormal very deuse tree of medium size; in cultivetion.

A. camestre L. Bumcan waple. A iom tree; in cultivation. Hipnosastanareat. Buskere Fnily.

AESCULUS.

AF. Hinnocastanum L. Horse-oinestmut. A smali or sometines large tree; cultivated; native of Asia.

AF. glabre Tiljd. Onio suckeve. ishmis to nediun sized tree; in poos cula in cultivation.

Tiliacea

TILIA

I. Anerisana L. Aaerisan Linzen. A handsome, first-oiass tree; in rooss niz cultivated.

T. hetorgungila Vent. Mite 3ass-mood. A small tree mith lorger leaves tilaj above; in woods and in cultivation. 

T. Furopaea $T_{1}$. Furopean tinden. Smazier. and nore dense than

T. Americana, also more formil; cultivated from Furcoe.

Cornaceae. Hogwond Family.

CCRNUS.

C. Floride $T_{1}$. Flowering Dogwood. A small tree or large simub; orten plutivater, rarely in woods.

C. Amonum Mi11. Kinmikinmik. A shrub in woods. Cmmon.

C. stolonifera Michx. Red-osier nogwood. A shmio often cultivated for effect of its red stems; comnon in roods.

C. alternifolia I,. A small tree or shrub. Common in voods.

Fricaceae. Heath Farnily. See Shrubs.

Thenaceae.

DTOSPYROS.

D. Viriginiana T, Persimon. A medium sized tree; sultivated, especially for fruit.

Oleaceae. Olive Farnily.

SYRTIGA.

S. vulgaris $T_{1}$. Lilac. A large shrub or small tree; conmon in gutivation.

S. persica T. Persian Tilac. A mose slender shmo thar above; in cultivation. 



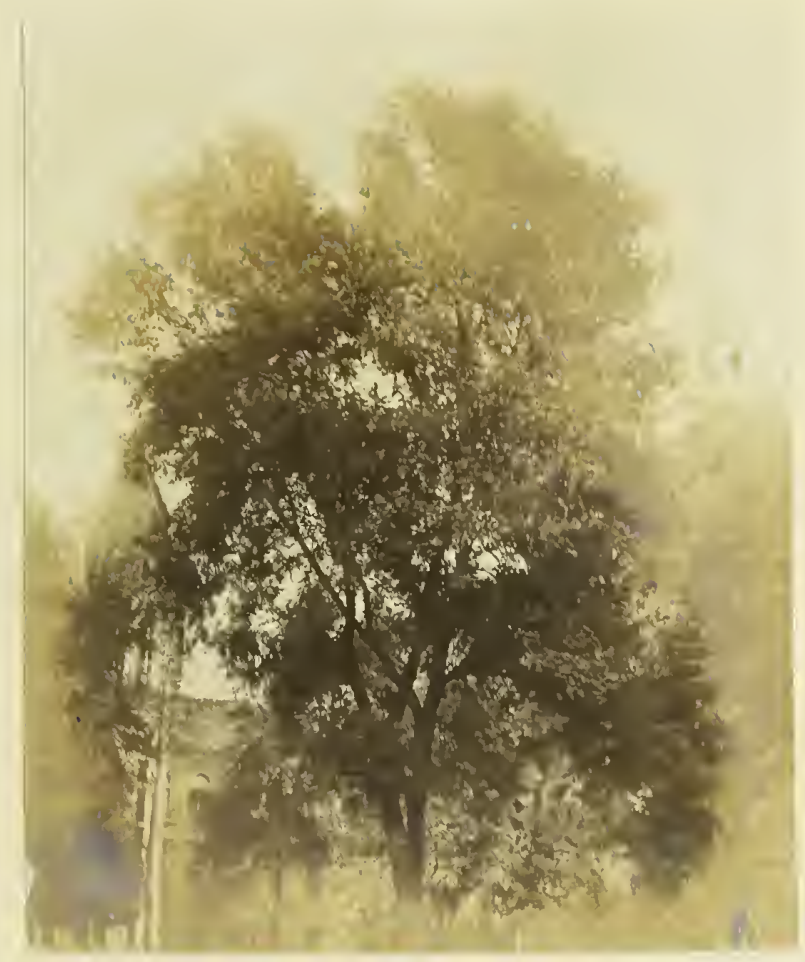

Fraxinus lanceolata. Green Ash. 

F. Anericana T. White Ash. A handsome large tree; in woods and cultivated; reaches its greatest develoment in this region.

F. Ianceolata Borck. Green Ash. Not so large as above. Cormon.

F. Penristvanica Marsh. Red Ash. Not so comnon as precodjng, species.

F. quadrangulata. Michx. Blue Ash. 1 large tree in woods and cultivation.

F. nigra Marsh. Black Ash. A large swamp tree; oceasionalJy in woods, and in altivation.

CHIONANTHIS:

C. Virginiana T. Fringe-tree. A shrub or smali tree cultivated for ornament. Tikely to winter-kizl in severe seasons.

Bignoniaceae.

CATAIPA. Very striking trees of North Arnerica, Fastern Asia and the west Indies. Usuat ry ixpegular in shape and rapid growers.

C. Catalpa $\left(T_{3}\right)$. Indian Rean. A mediun sized tree usucl IV $\forall i t h$ flat spreading top, Jeaves large. cultivated.

C. speciosa Warder. Isarge Indian Bean. Targer, more unright growing tree with larger leaves than above.

C. Koempferi sjeb.\&. Fuce. Japanese catalna. Smaljer and of less value than two preceding species. Cultivated from Japan.

Rubiaceae. See Shmubs. 

Caprifoliaceae. See shmins.

SIIRUBS, INCLIHDINC WOCDY VIISGS.

Although there is no definite line separating sinubs froin trees, we find they constitute cuite an extensive and distinct groun in themselves. The thickets and woods contain a number of native species, wile many others are fount here that have been introkuced through cultivation. owing to the limited anount of omamental nlanting, within reach for investigation the list is not conn?ete. It is sonewhat inexact too, owing to the fact that many species have been reported from only one or two specimens, and misht not psove satisfactory for general use. As a whole, however, the liat is fairly renresentative of the shrubs that do thrive in this locality, and all the common species are included.

Gynnosnerris.

THUJA. See Sirrubs.

JUNIPFRIS. See Trees, also

J. Sabina T, Srmubisy Red Cedar. A Jow or trailing shmib; orten cultivated, especially on rockeries.

Angiosperrns.

Monocotyledons.

Tiliacoae.

No true shrub in this losality, though vucesa filamentosa Is. is 

sometimes classed as one.

Snijareae.

ShLtAX. Climbjeng, usually prickly vines. conly one perennial species common here.

S. hispida luhl. Greenbrier. A high climbing vine in woods. Not of any value for cultivation.

\title{
Dicotyledons.
}

I ike the trees that occur here the shrubs are chierly of highy complex stmucture, and belong to the class of dicotyledons.

Betulface.

COFY TIUS.

C. Americana WaIt. Hazelnut. A sma.l to mediurnsized shrub; in thickets and sometimes cultivated. c. rostrata nit. Reaked Hazelmut. Very similar to above species.

C. Aveliana I. Furopean Hazelnut. Filhert. A mall tree or snrub; cultivated from Furone. (Agricultural isxeriemnt station).

\author{
Magnoliaceae.
}

MAGNTIA. See Trees.

Tamariscineae.

TAMARLX

T. Gallica J. Prench or Comnon Tamarisk. A sinruh with 

long slander drooning branches. Cultivatied from old Vorld. FIowers very small, armearing before leaves. Somewhat liable to winter-kill.

Ranunculaceae. Yrowfoot farnily.

CIPMATIS, CIimbing vines or erect horbs of wide geowriphical. distribution.

c. Virginiana $T_{\text {, }}$ yirgins Rower. Isong vine o rapia growth; common in cultivation.

C. Tackmanii. Jacknan's Hybrid clematis. A handsome flowering vine, good for trellises. occasionally dangged by severe winters.

ATRAGENE.

A. Americana sims. Purple Virgir's Bower. A trailing or clirabirg vine; comrnon in cultivation.

$$
\text { Rerberidaceae. }
$$

RFRRTRIS.

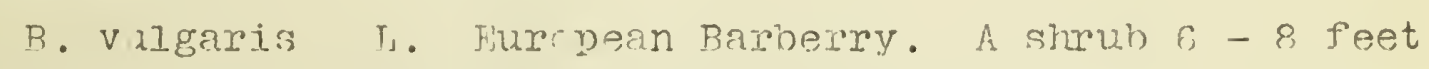
high; cormon in cultivation. Forms a very handsome head. Variety purpur эa, a shrub mucl like the last but with purple jeaves iss also cultivated.

B. Thunbergii DS. A low shrub introducea from Janan.

$$
\text { Menispermaceae. }
$$

MFNISPERMIJM - Only one species native to North Anerica. M. Canadensa Is. Canada Moonseed. A clirning vine in woods and cultivated, prefers noist places. 



\section{Calvcanthaceae}

\section{RITNFRIA.}

B. Plorida $r_{1}$. Plowering Shrub. A medjum-sized to Iaree shrub; colmon in cultivation; introduced fron fartier north.

\section{Isauracea?}

BEN7OIN. A group of shrubs of Jorth America ancl Fastern $\Lambda$ sia. B. Renpoin $T_{1}$ spice Push. A large shrub; common in fiejds and woods.

Saxifragaceae.

DEIIZIA.

n. gracilis Sieb. \&. Zucc. A small shrub from Janan; does not stand winter well.

D. scabra Trunb. A tall shrub from China and Janan, also cuite tender.

HYDRANGEA. $\Lambda$ genus of about thirty-five species in North America, Eastern Asia and the Hinalayas. one snecies native here, others in cultivation.

H. arborescens I. Wild Hydrangea. occurs liere as a mediumsized shrub along banks of strearns.

H. paniculata Siel). Commor 0.xt-door or Hardy Hydrangea. A medium-sized broad spreading shrub. Huch used in planting, esperial1. variety Grandifiora. CuItivated from sapan. 

PHITADFIPHIJS. Hock Orange.

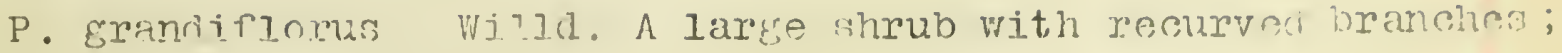

cultivated from farther south.

n. coronarius I. cormon Syringa or kock orange. $\Lambda$ shrub with erect iranches; comion; cultivated from southern Furone.

Grossulaceae. Gooseberry Farnily.

RIBFS. Several species comnoy in roods and in cultivation.

R. Cynosbati T. Wild Gooseberry. A small whrub in wonds, not. ornamental.

R. gracile Michx. Missouri Gooseberry. A common wild shrub.

R. ruhrum $T_{1}$. Common carden Red currant .

R. aureum Pursh. Missouri currant. A large handsome shrub flowering in early spring; cultivated and escaped.

Hamamelidaceae.

HAMAMELIS .

H. Virginiana L. Witch Hazel. A shrub or small tree; cultivated, and roported from woods.

Rosaceae. Rose pamily.

OPUTJASTFR.

0. opulifolius $T_{1}$. Iinebark. A shrub, native farther north and east, cultivat ol here in shrubberies. 

SPIRAFIA.

S. Salicifolia T. American Meadowsweet. A 10 to mediunsized shrub; common in cultivation.

S. Japonica $T_{1}$. A shrub from Japan. Cultjvated in iniversity of Ilinois grounds.

S. Thunbergii sieb. A dwartish shrub vith delicate branches; with many small white flowers in early spring. Cultivated from Japan.

S. trilobata I. A spreading bush; cultivated from

Siberia.

RUBUS. A group or perennial herbs, shrubs, or traijing vines.

R. odoratus T. Purple-flowering Raspberry. A bristzy shrub; cultivated for flowers.

R. strigosus Michx. Wild Red Raspberry. Comnon in woods, varieties cultivated for rmit.

R. occidentalis Is Black Raspberry. Ocours in woods, varieties cultivated for fruit.

R. viliosus Ait. High Bush Blackberry. Common in woods and in cultivation.

ROSA. Frect or climbing shrubs, generally having prickly stems, several species wild, others in cultivation.

R. setigira lichx. Prairie or climbing Rose. Comron in thickets.

R. blanda Ait. Meador Rose. Common in woods.

R. humizis Marsh. Tow or Pasture Rose. Occurs in woods.

R. rubiginosa $T_{1}$. Sweetbrier. Fscaped, and in cultivation.

R. Fglanteria Is. Vellow Rose. Comon in cultivation. 

R. spinosissima T. Scotch Rose. A specjes cultivated from Furope.

sevaral other exotic species are hardy here, and are mltivated.

KIIRRIA.

K. Japonica DC, Japanese Rose. A small shrub with hright yellow flowers ant briknt green leaves; cultivated fron Janan.

Ponaceae.

CRATAEGUS See Trees.

Drupaceae.

PRIMIIS. See Trees.

Papilionaceae. Pea Family.

A)'ORPHA.

A. fruticosa $r_{1}$. False Indigo. A large shrub native in cur roods.

A. cansiscens Pursh. Tead Plant. $\Lambda$ small prairie sinruh or herb, native here.

KRAUNHIA. Wisteria, a group of four species, three Asiatic, one American.

K. frutescens $\left(T_{1}\right)$. American Wi iteria. A largo rapid growing vine tiat reaches thirty or forty feet in length; cornon in cultivation, especially upon piazzas. 

Anacardiaceae. Sunac Family.

RHUS. A class of rather coarse shrubs good for backgrounds and thicket planting.

R. hirta $T_{1}$. Staghorn Suriac. A large shrub or small tree, not comnon nol or very general distribution in our locality.

R. Glabra $T_{1}$. Smooth or scarlet Surnac. A nediun-sired shrui; commor in woodis and thickets.

R. radicans $T_{1}$. Poison or Three-leaved Trv. A w icdv, climbing or exect and bushy vine. Common in thickets, on trees, arid on fences.

COTINUS.

C. cotinoides (Nut,t). Wild American Snoke riree. A large shrub or small tree. comnon in cultivation, belongs farther south.

Celastraceae.

FUTNYMUS .

F. ocioratus Ilutt. Running Strawberry bush. A $10 \mathrm{~m}$ decumbent shmub; occasionally found in woods.

F. atropurpureus Jaca. Wahoo. A shrub or small tree, common in woods. Ornamental, especially when in fmit.

E. Firopaeus $T_{1}$. Spindle tree. A shrub much Jike above. Cultivated from Furope.

CFLASTRUS .

C. scandens $T_{1}$. Shrubby or climbing Bittersweet. A twining woody vine. In woods. 



\section{staphyleaceae.}

STAPHVLEA.

S. trifoliata T. American R.tadder nut. A large shrub; in woods; not very ornamental.

Hippocastanaceae.

AFsculus See Trees.

Rharnnaceae.

RHAMNUS.

R. eathartica $T_{\text {, }}$ Ruckthorn. A large shrub, often tinorny; occasionally grown in cultivation.

R. J.anceolata Pursh. Janse-leaved Buckthorn. Reported from Fnglewood, Illinois. Common in scuthern Illinois.

R. alnifolia. Reported from Elgin, Illinnis. CEANOTHUS.

C. Americana $T_{1}$. New jersey Tea. Red-root. A small shrub, common on prairie land.

Vitaseae. Grape Family.

A family of very vide aistribution.

VITIS. Grape vine. Many species and varieties cultivated for fruit, the rollowing ones in woods. 

V. Trabruscia T. Sweet-scented Grape.

V. aestivalis Michx. Sumner Grape.

V. cinera Mrgeln. Jowry Grape.

V. cordifolia Michx. Frost Grape oc chicken Grape.

AMP FT,OPSIS.

A. cordata líchx. Cisșs. Reported from Grafton, IIIinois. (Seymour).

\section{PARTHFNOCISSUS.}

P. quinquefolia T. Virginia Creeper. A high climbing vine; in woods and often cultivated.

P. tricuspidata (Sieb \& Zucc). Japanese Ivy. $\Lambda$ high climbing vine from Japan; Inucll sultivated, especially on buildings.

Thymeliaceae.

D)APHINT,

D. mezereum T, spruge raurel. A small shmb; has been tried here; should do well.

DIRCA .

J). palustris T, T,eather-wood. A small to medium-sized shrub; in thickets.

Cornaceae.

CORNUS. See Trees. 

RICIODFIDROIN.

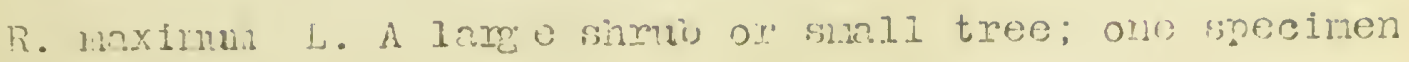
roma in al Itivation, iut not in goox conjition.

0leacest.

SYRIiva. See Trees.

PORNYTHI:

ت. viridissilo Lindl. A malz vigorous, drooping, ormamen-

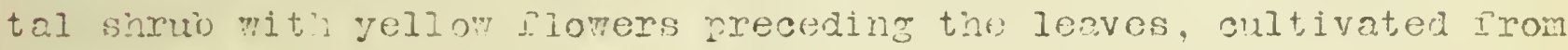
ChInE and Japai.

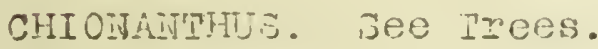

ILTUSTRTILA.

I. Virlgart: I. Plivet. A simmo often used for hedges, does mel 1 here.

Bi moni soeae.

TECOIIA.

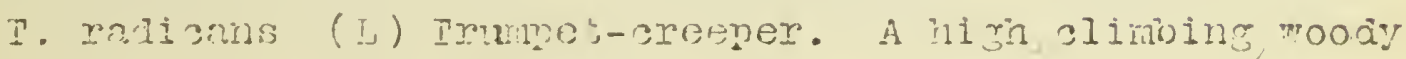

vine; omran? tu oultivation, and escapea.

$$
\text { Rut asegr? }
$$

CEPHALAITIIU.

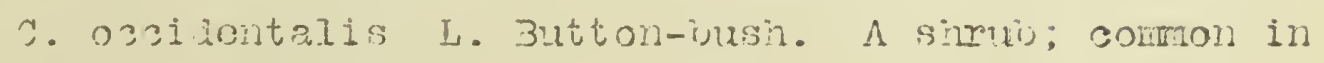



coprtenticos?

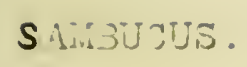

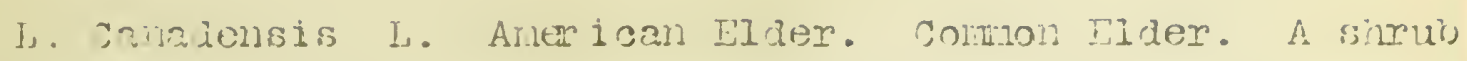
Hitin stems moody only near tix wase; sommon ir moods; rood for mixod siruibery.

VISTRITI:-

V. Opurus L. Sieen Berny. S"eet, Viburumuin. A sinrui or sm 11 troe. Reportei nere. (c. P. Cilnton). Var. = Snowball Tree. V. prunifoliun L. BIack Hat. A Iarge siruib; comon in 7oods, oultiveted ix ornariont.

V. Isuthina L. Woysaring Iree: A large simui, mith hondsome dense head; cultivatoa from firmone.

SYIPHORICARPOS.

5. rasenos!s wishy. Fnowerry. A sinil erect shruis, with samy mite ierrios in cutun; comon ir garjens; oultivated from Europe.

5. Symphorizarpos (L). Indian currant. A small shmis; conton in moous, sometimes cultirated.

LONIGRA. Freot or alining shrubs, mell adented to this locality.

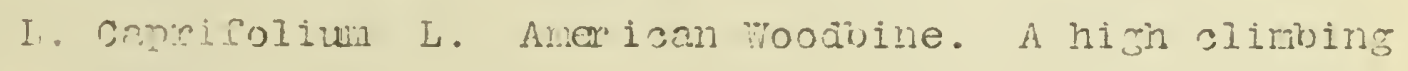
vine matil alized froul Europe; cultivated. 



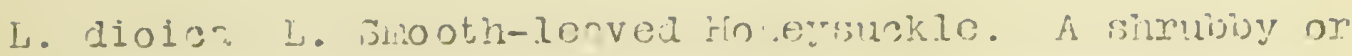

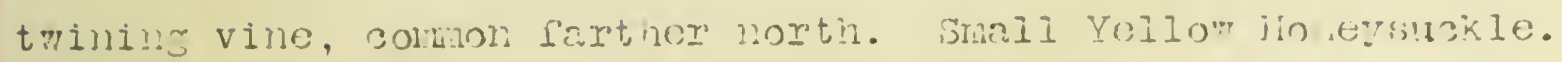

L. Sulluantic irne. A siruidis vine; oultivated.

I. sompervinons L. Tmunet Honevsukle. A him olinbing vine; connon in cultivation.

I. Tannul:? anis. japanese Honeysuckle. A vine naturaIized from easturin Mia; in cultivation. (I.J.B.)

L. Cilata Muni. Merican Fly Hoversuckie. A small shmab; in cultivation. (I.J.3.)

L. Tartorica I. Bush Honeysuckle. A large simub; conton in cultiva.tion.

\section{DIERVILEA}

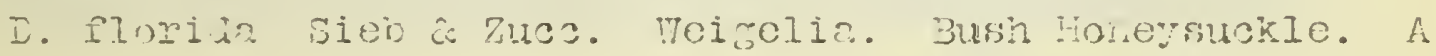
shall to nediun-gized shruij: comon in cultivation. From China and Japan.

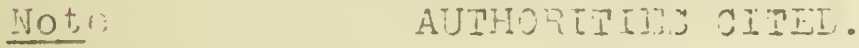

31 - Frederiax 3rendel, peoria, III.

Bryant - R. $\approx$. Bryant, Pringeton, III.

T.J.B. - Dostor I. Jurriil, University of illinois.

F.P. . - G. P. Clinton, Univeristy or Illinois.

GI. - H. A. Gleaknin, University of ilimois.

Hall - ir. Hall. A Iormer botanist or Illinois.

serriour - A. 3. Seynor, forneriy in University of IlIimois.

Vasey - Dodtor areorge vasey. A former botanist of Illinois. 



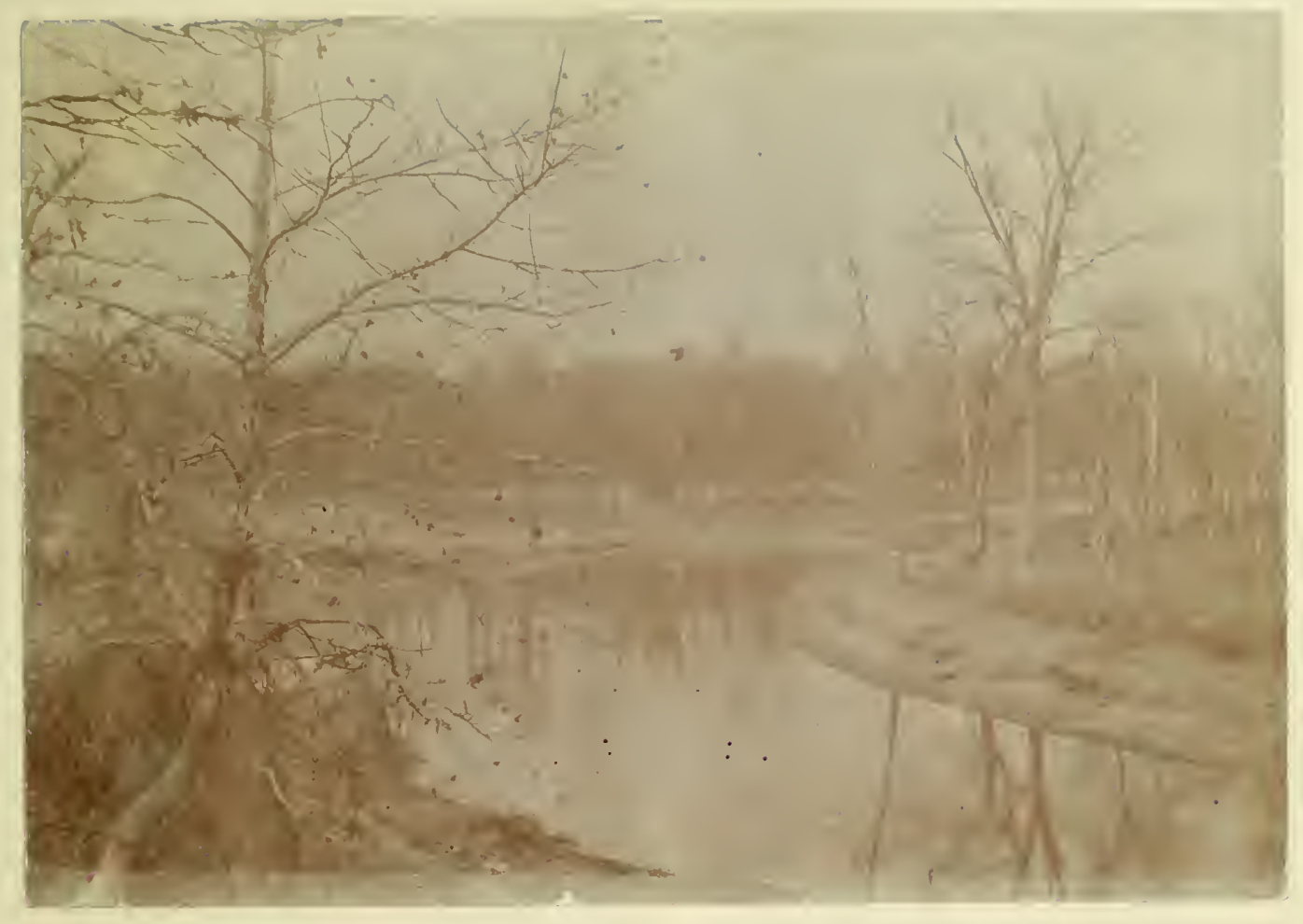

sycamore.

Anerican EIm. 



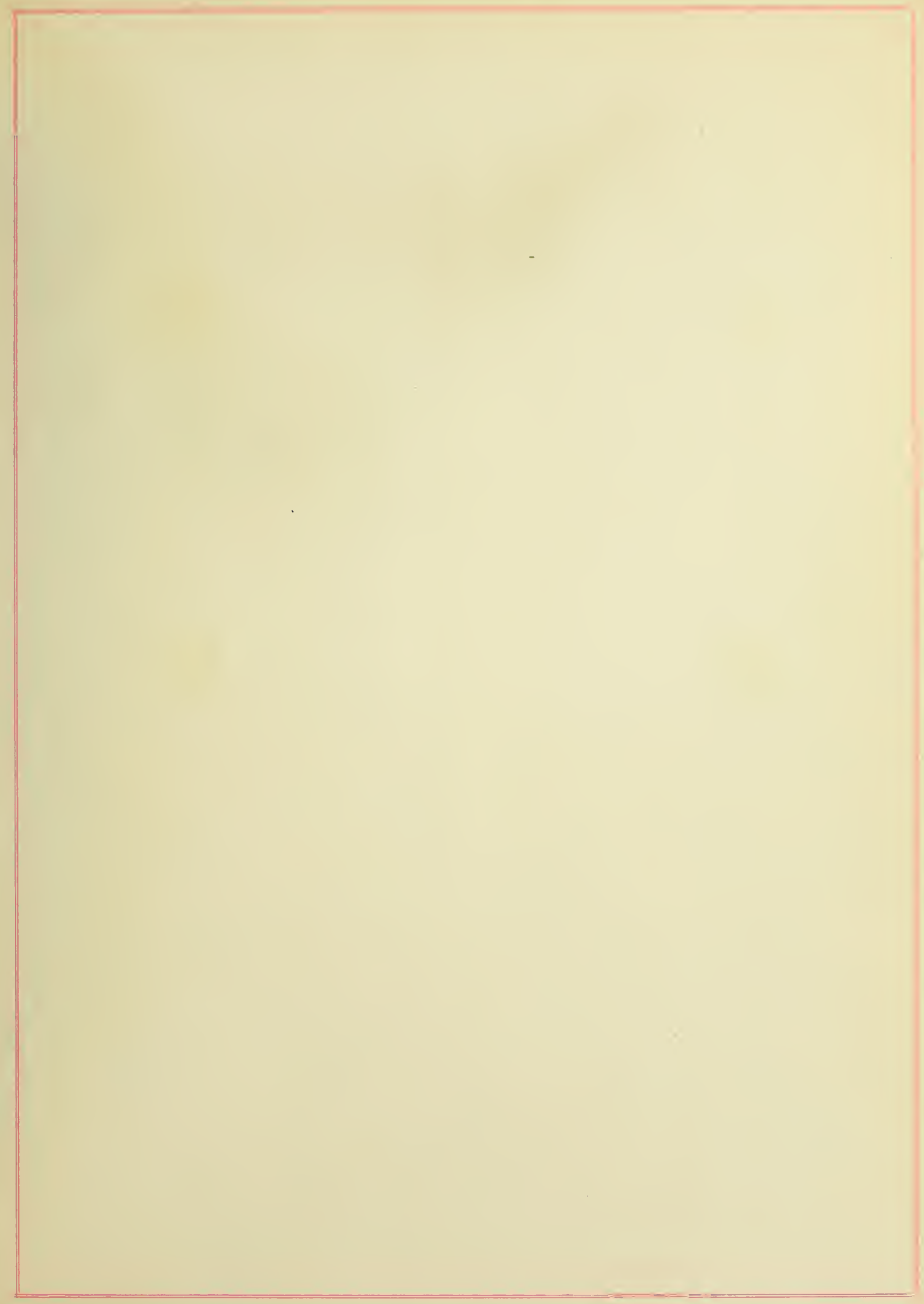





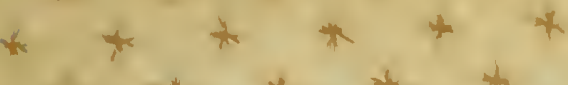

.

$+x+4+4 \times+4$

$x$

* $x+k+* x+4$

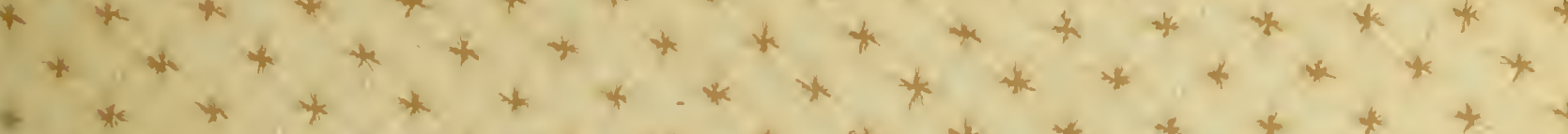

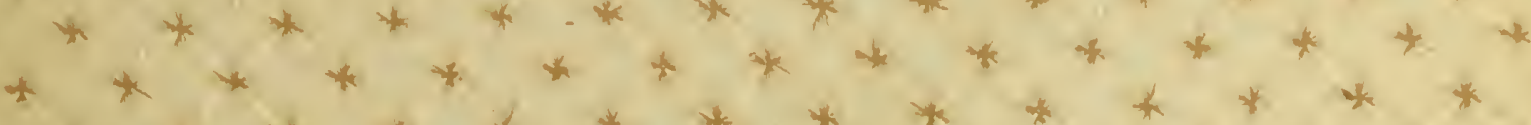

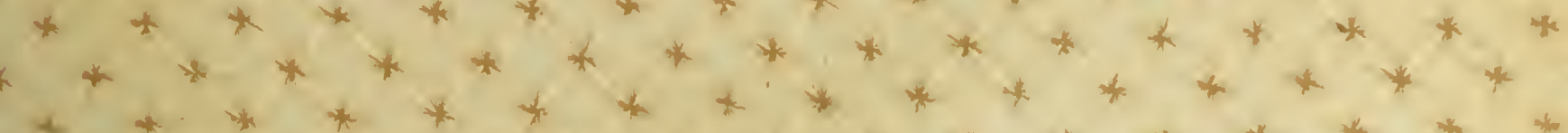

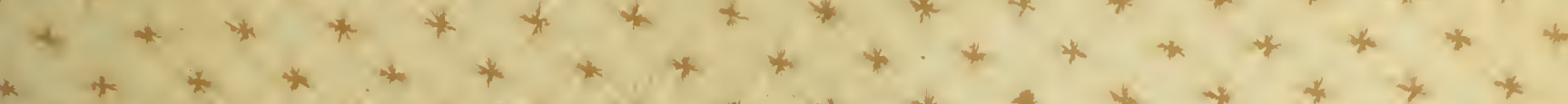
$* \quad *+*$

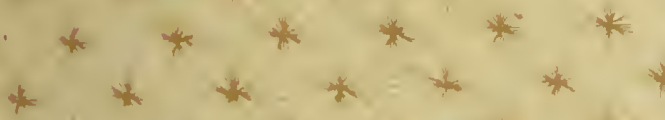

$*$

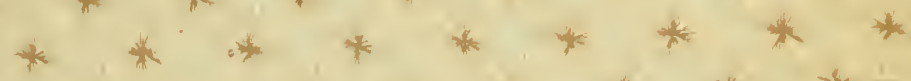

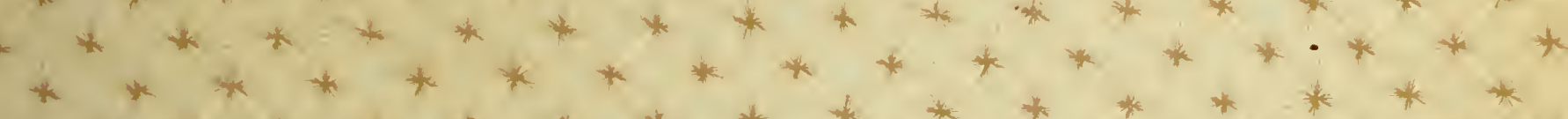

* * * * * * * * * * * * * * * * * * * * * * * * * * * * * * * *

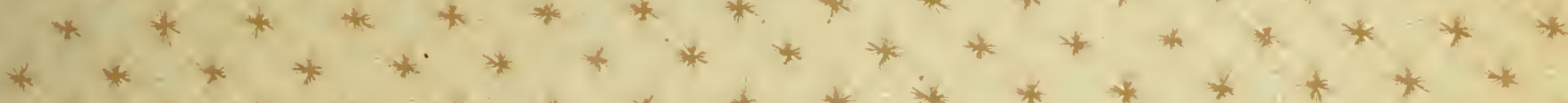

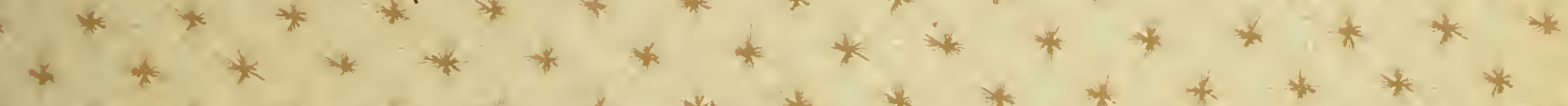

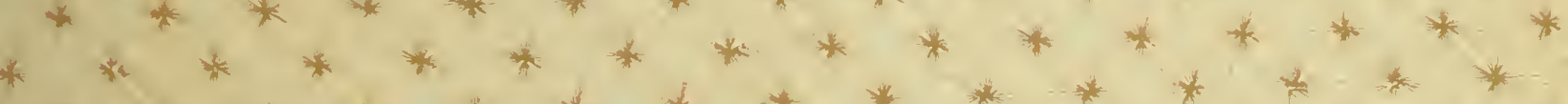

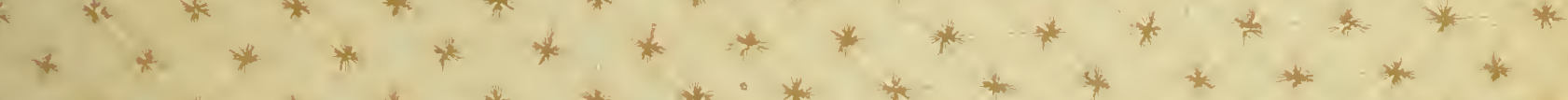

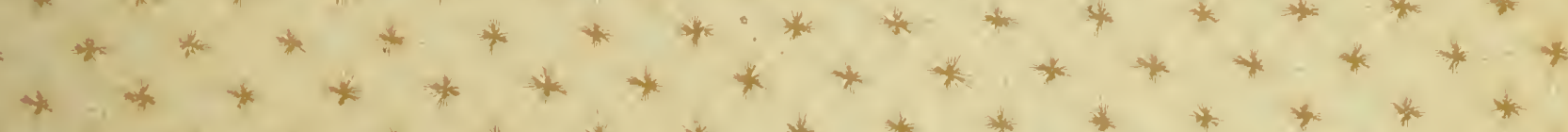
$* * * * * * * * * * * * * * * * 4$ * $* * * * *$

*

* *

$* * * * * * * * *$

$+*$

** * * * * * * *

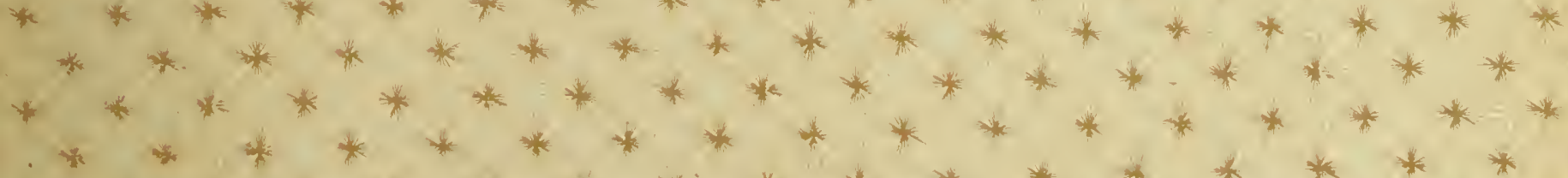

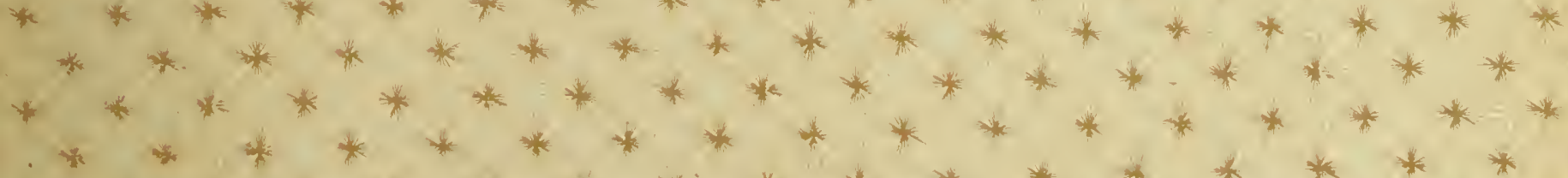

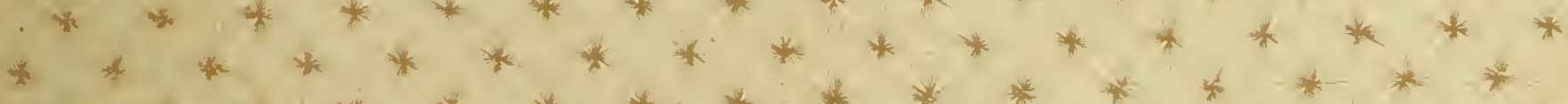

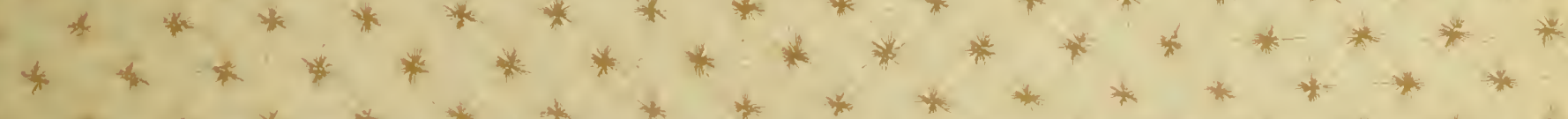
$* \quad \% \quad \%$

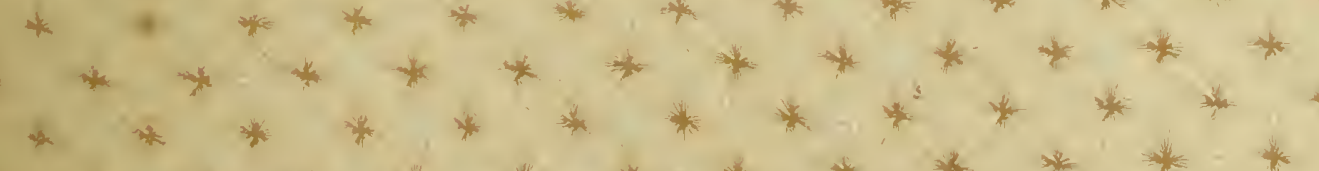
* * * * * * *

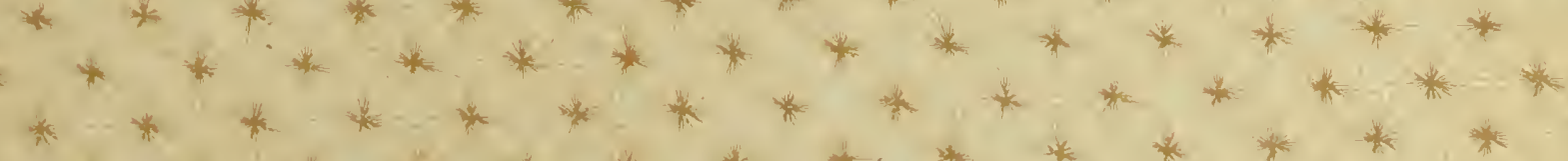

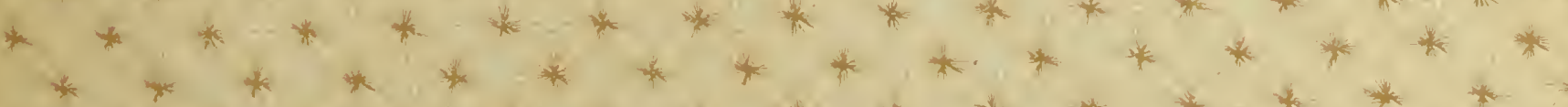

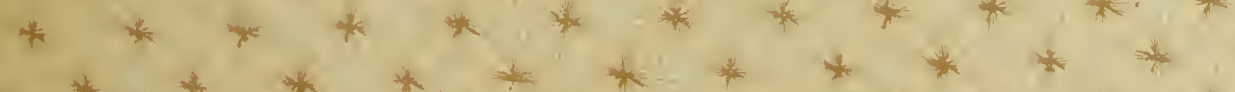




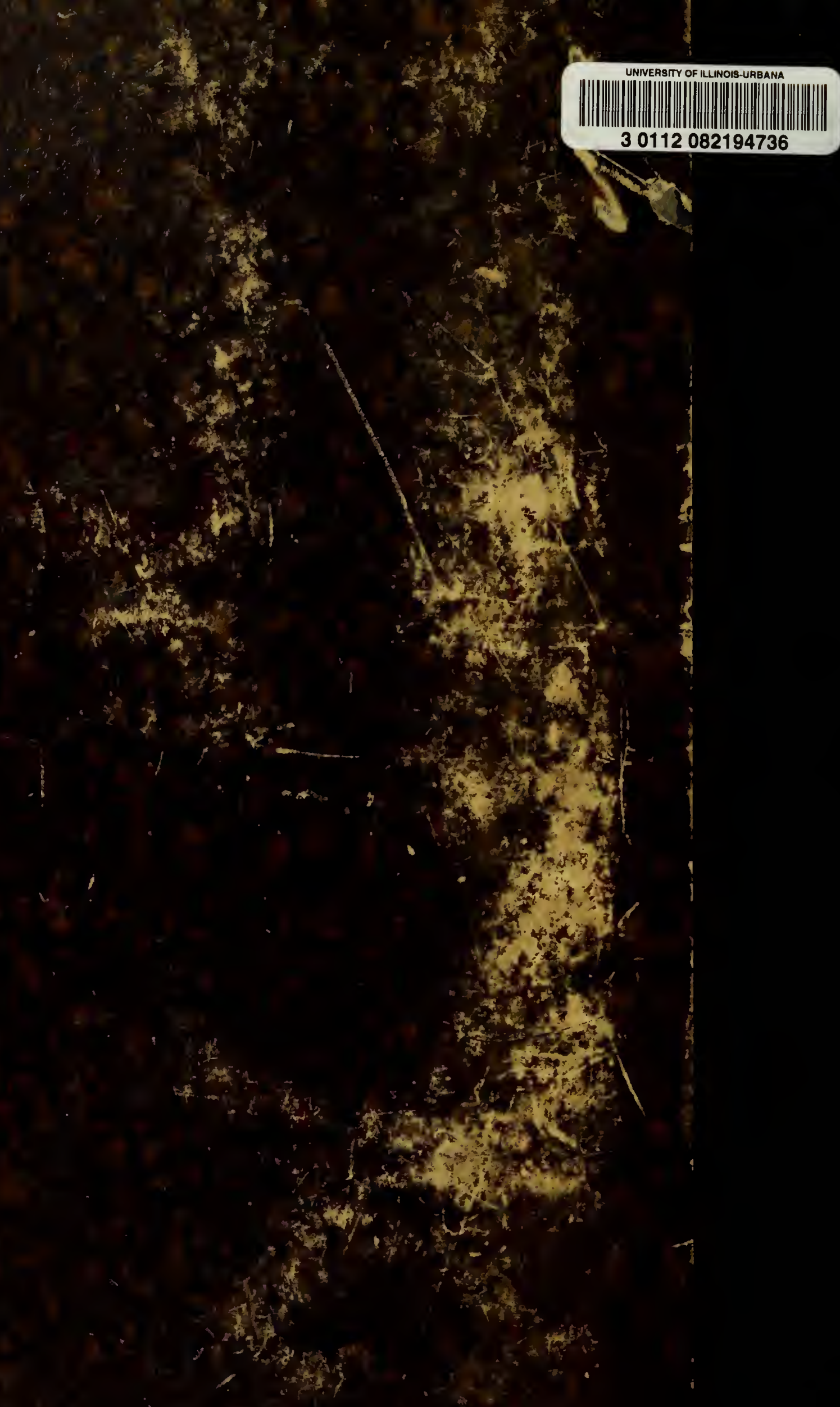

